\title{
Application of Supramolecular Microextraction and Flame Atomic Absorption Spectrometry for Ultra-trace Determination of Cadmium in Food and Water Samples
}

\author{
Z.A. ALOthman ${ }^{a}$, M.A. Habila ${ }^{a}$, Erkan Yilmaz ${ }^{b}$, M. Soylak ${ }^{\text {b, }}$, and A.A. Alwarthan ${ }^{a}$ \\ ${ }^{a}$ Chemistry Department, College of Science, King Saud University, Riyadh 11451, Kingdom of Saudi Arabia \\ ${ }^{b}$ Erciyes University, Faculty of Sciences, Department of Chemistry, 38039 Kayseri, Turkey
}

\section{INTRODUCTION}

Metal ions at trace or ultratrace levels are generally problematic for humans, plants, and animals (1-3). Lead $(\mathrm{Pb})$ and cadmium $(\mathrm{Cd})$ are very toxict metals even at trace levels, whereas zinc ( $\mathrm{Zn}$ ) and copper $\mathrm{C} \mathrm{Cu})$ are toxic only when they are present at higher concentrations (4-7). Excessive use of fertilizers can accumulate trace elements in the soil, causing high toxicity to the environment and plants. Cadmium contamination in the food chain can be harmful and cause chronic health problems (8-13).

The determination of cadmium and other metals at trace or ultratrace levels by spectroscopic techniques are an important area of chemistry, agriculture, medicine, biology, etc. (14-20). Due to the low detection capabilities of these techniques, the matrix effects and low levels of the analyte elements in some samples are two important problems (21-25). Preconcentration-separation systems, including solid phase extraction, cloud point extraction, coprecipitation, membrane filtration, electrodeposition and flotation, are an important key to solve these problems (26-29).

In the last decade, microextraction techniques have become an alternative for the preconcentration-separation techniques due to advantages such as limited consumption of organic solvents, the possibility of high preconcentration factors, and easy application

\footnotetext{
*Corresponding autbor.

:E-mai: soylak@erciyes.edu.tr

Fax: +903524374933
}

\author{
ABSTRACT \\ In this work, a supramolecular \\ microextraction procedure for \\ trace cadmium as 1,2,4 thiadia- \\ zole-2,5 dithiol chelates has been \\ established. Flame atomic absorp- \\ tion spectrometry was used for \\ the determination of cadmium. \\ A rapid injection of $600 \mu \mathrm{L}$ \\ tetrahydrofuran and $200 \mu \mathrm{L}$ of \\ 1-decanol in a sample solution \\ containing cadmium at $\mathrm{pH} 8$ \\ leads to formation of a cloudy \\ solution by ultrasonic waves. \\ Then the supramolecular organic \\ solvent mixture, including the \\ chelated cadmium, was separated \\ by centrifugation. Certified refer- \\ ence materials (TMDA 64.2 and \\ TMDA 53.3) were tested and the \\ determined concentrations were \\ in agreement with the certified \\ values. Furthermore, the method \\ resulted in an LOD of $0.46 \mu \mathrm{g} \mathrm{L}^{-1}$, \\ LOQ of $1.37 \mu \mathrm{g} \mathrm{L}^{-1}$, and RSD of \\ $5.1 \%$. The supramolecular \\ microextraction procedure was \\ successfully applied for the analy- \\ sis of environmental samples \\ including wastewater, seawater, \\ dam water, valley water, and \\ black pepper.
}

to real samples, etc. (30-33). The use of suitable new solvents in microextraction studies which are environmentally friendly and green is a challenge that has been discussed by analytical chemists (34-36). Supramolecular solvents (SUPRAS) for microextraction are a good choice (36-38). SUPRAS has been introduced as an extraction method with many advantages such as low use of organic solvents, high pre-concentration factors, and fast and simple procedure based on a self-assembly process of the supra- molecular solvent. This procedure allows the different polarity sites in these assembly constituents and provides a suitable environ-ment to separate and preconcentrate the analytes (36-38).

A novel and simple supramolecular microextraction procedure based on the extraction of Cd(II) as 1,2,4-thiadiazole-2,5-dithiol chelates is presented in this work. The analytical conditions for quantitative extraction of $\mathrm{Cd}$ (II) were optimized.

\section{EXPERIMENTAL}

\section{Instrumentation}

A PerkinElmer® Model 3110 flame atomic absorption spectrometer (PerkinElmer, Inc., Shelton, CT, USA) with an air-acetylene flame and hollow cathode lamp was used to measure cadmium concentrations. The instrumental operating parameters and linear range for cadmium are listed in Table I. The instrumental parameters were adjusted as recommended by the manufacturer. The samples were injected into the AAS with a Teflon ${ }^{\circledR}$ funnel using a homemade micro-sample introduction system. The absorbance signal was measured according to peak height in the continuous aspiration mode (39).

A Nel pH-900 (Ankara, Turkey) and Metrohm pH meter (Model 691, Switzerland) with a combined glass electrode were used for the pH measurements. An ALC PK 120 Model centrifuge (Buckinghamshire, England) was used for centrifugation. A vortex mixer (VWR International LLC, USA) and an ultrasonic bath (Sonorex, Model No. DT-255, Bandelin Co., Germany) were used. 


\section{Reagents and Standard Solutions}

All chemicals were of analytical grade. Distilled and deionized water with $18 \mathrm{M} \Omega$ resistivity were prepared using a Milli-Q ${ }^{\circledR}$ system (Millipore Corporation, USA). Stock Cd(II) solutions (1000 $\mathrm{mg} \mathrm{L}^{-1}$ ) were prepared by dissolving the nitrate salt in water (E. Merck. Darmstadt, Germany). Working standard solutions were obtained via serial dilution of a stock standard solution. The $0.1 \%(\mathrm{w} / \mathrm{v})$ 1,2,4-thiadiazole2,5-dithiol (Sigma-Aldrich, St. Louis, MO, USA) solution was prepared using deionized water.

\section{Procedure}

A 20-mL sample solution containing Cd(II) was placed into a $50-\mathrm{mL}$ polypropelene centrifuge tube and the $\mathrm{pH}$ was adjusted to 8 using an ammonia buffer solution. Then $200 \mu \mathrm{L}$ of $0.1 \%$ 1,2,4-thiadiazole2,5-dithiol ligand was introduced. In this step, the chelation of Cd(II) with 1,2,4-thiadiazole-2,5-dithiol tetrahydrofuran and 1-decanol was rapidly injected into the mixture which leads to the formation of supramolecular solvent inside the tube. The mixture was exposed to ultrasonic waves for 4 to 5 minutes and then shaken on the vortex for one minute. Finally, the phase was separated by using the centrifuge at $4000 \mathrm{rpm}$ for 10 minutes. After removing the bottom aqueous phase, the remaining supramolecular solvents containing cadmium as 1,2,4-thiadiazole-2,5-dithiol chelates were dissolved in ethanol to complete the final volume to $500 \mu \mathrm{L}$. The Cd(II) concentration was determined by injection of $50 \mu \mathrm{L}$ into the AAS with a Teflon ${ }^{\circledR}$ funnel occurred. Then, a solution of

using a homemade micro-sample introduction system.

\section{Application of Method to Real Samples}

Water samples, including wastewater, seawater, dam water, and valley water were obtained in Turkey. The samples were filtered with a Millipore ${ }^{\circledR}$ cellulose membrane ( 0.45 micrometer), then the optimized supramolecular microextraction procedure was applied for Cd(II) determination. Certified reference materials for water such as TMDA 64.2 and TMDA 53.3 (National Water Research Institute, Environment Canada, Burlington, Canada) were applied to evaluate the process. In addition, black pepper as a food sample from Kayseri City, Turkey, was collected, washed, dried, and digested as described in the literature $(31,39)$. The proposed supramolecular microextraction steps were applied to the food sample extract for Cd(II) determination.

\section{RESULTS AND DISCUSSION}

\section{Optimization of Analytical Parameters}

The significant parameters controlling the supramolecular extraction steps including $\mathrm{pH}$, amount of 1,2,4-thiadiazole-2,5-dithiol as ligand, composition of supramolecular mixture, and sample volume, were optimized.

The $\mathrm{pH}$ of the sample solution containing Cd(II) was tested in acidic, neutral and basic medium up to $\mathrm{pH}$ 9. Figure 1 shows the effect of $\mathrm{pH}$ on the recovery of Cd(II). The quantitative recovery was achieved at $\mathrm{pH} 8$ which was

TABLE I

Instrumental Operating Conditions and Linear Range for Cadmium

\begin{tabular}{|c|c|c|c|c|}
\hline Element & $\begin{array}{l}\text { Wavelength } \\
\text { (nm) }\end{array}$ & $\begin{array}{l}\text { Slit Width } \\
\text { (nm) }\end{array}$ & $\begin{array}{l}\text { Lamp Current } \\
(\mathrm{mA})\end{array}$ & $\begin{array}{l}\text { Linear Range } \\
\left(\mu \mathrm{gL} \mathrm{m}^{-1}\right)\end{array}$ \\
\hline $\mathrm{Cd}$ & 228.8 & 0.7 & 4 & $0.1-2.0$ \\
\hline
\end{tabular}

selected for further investigations. It was reported earlier that the $\mathrm{pH}$ of a sample solution significantly affects the recovery of heavy metals $(14,16,18,21)$.

The volume of 1,2,4-thiadiazole2,5-dithiol as ligand was tested in the range of $0-300 \mu \mathrm{L}$ and the (\%) recovery was calculated for each case. Figure 2 demonstrates that the (\%) recovery values were very low at 0,25 , and $50 \mu \mathrm{L}$, then increased at 100 and $150 \mu \mathrm{L}$. Quantitative recoveries were obtained between 200 to $300 \mu \mathrm{L}$. The increase in recoveries between increasing volume of ligand solution can be attributed to the fact that the microextraction procedure depends on the formation of a complex between Cd(II) and 1,2,4-thiadiazole-2,5-dithiol as the ligand. This complex will leave the aqueous phase and move to the organic supramolecular solvent phase which separates later and is measured. When using a limited amount of 1,2,4-thiadiazole-2,5dithiol ligand, it will not be enough to chelate all Cd(II). Therefore, $200 \mu \mathrm{L}$ was chosen for further experiments.

The component of the supramolecular solvent is reported to have significant effects on the recovery of metals (39). Therefore, tetrahydrofuran with 1-decanol, tetrahydrofuran with undecanol, and tetrahydrofuran with decanoic acid were tested as different supramolecular solvents and the recovery was 99\%, 18\%, 7\%, respectively. Tetrahydrofuran was selected for further work due to quantitative recoveries.

The volume of tetrahydrofuran and the amount of 1-decanol were investigated in the range of 0-800 $\mu \mathrm{L}$ for tetrahydrofuran and in the range of $0-250 \mu \mathrm{L}$ for 1-decanol. The quantitative recoveries (>95\%) were obtained for 600-800 $\mu \mathrm{L}$ of tetrahydrofuran and for $200-250 \mu \mathrm{L}$ of 1-decanol. For further work, 
$600 \mu \mathrm{L}$ of tetrahydrofuran and 200 $\mu \mathrm{L}$ of 1-decanol were selected.

The effect of sample volume is a controlling parameter which directly affects the preconcentration factor (40-46) and was studied in the range from $10 \mathrm{~mL}$ to $45 \mathrm{~mL}$ (Figure 3). The results show that the recoveries for Cd(II) were quantitative up to $20 \mathrm{~mL}$. The preconcentration factor calculated as the ratio between the initial volume of the Cd(II) sample and the last volume after supramolecular microextraction was 40 , considering that the last volume is $0.5 \mathrm{~mL}$.

The optimum conditions for the quantitative recoveries of Cd(II) as 1,2,4-thiadiazole-2,5-dithiol chelates for the presented supramolecular extraction method are summarized in Table II.

\section{Matrix Effects}

The studies on the effect of common interfering ions on the recovery of analyte elements are important for the optimization of separation-preconcentration methods (47-54). This was tested by applying the supramolecular separation- preconcentration steps in the presence of $\mathrm{K}^{+}, \mathrm{Cl}^{-}, \mathrm{Mg}^{2+}, \mathrm{Ca}^{2+}$, $\mathrm{SO}_{4}{ }^{2-}, \mathrm{F}^{-}, \mathrm{Ni}^{2+}, \mathrm{Cu}^{2+}, \mathrm{Fe}^{3+}, \mathrm{Zn}^{2+}$, $\mathrm{CO}_{3}{ }^{2-}, \mathrm{NO}_{3}{ }^{-}$, and $\mathrm{Na}^{+}$. Table III presents the \% recovery of cadmium for each ion which was not less

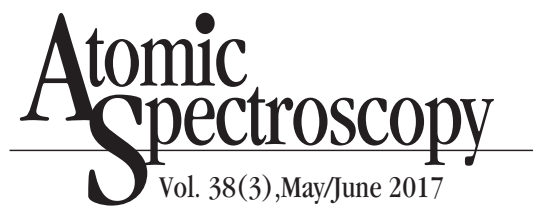

than $96 \%$, indicating that these supramolecular extraction steps can be applied for different samples with various matrices.

\section{Analytical Figures of Merit}

The LOD for this process was $0.46 \mu \mathrm{g} \mathrm{L}^{-1}$, the LOQ was $1.37 \mu \mathrm{g} \mathrm{L}^{-1}$, and the relative standard deviation (RSD) was 5.1\%. The supramolecular microextraction procedure described in this work was compared with others from the literature (55-61) and showed comparable results (Table IV).

\section{Application}

Validation of the presented supramolecular microextraction

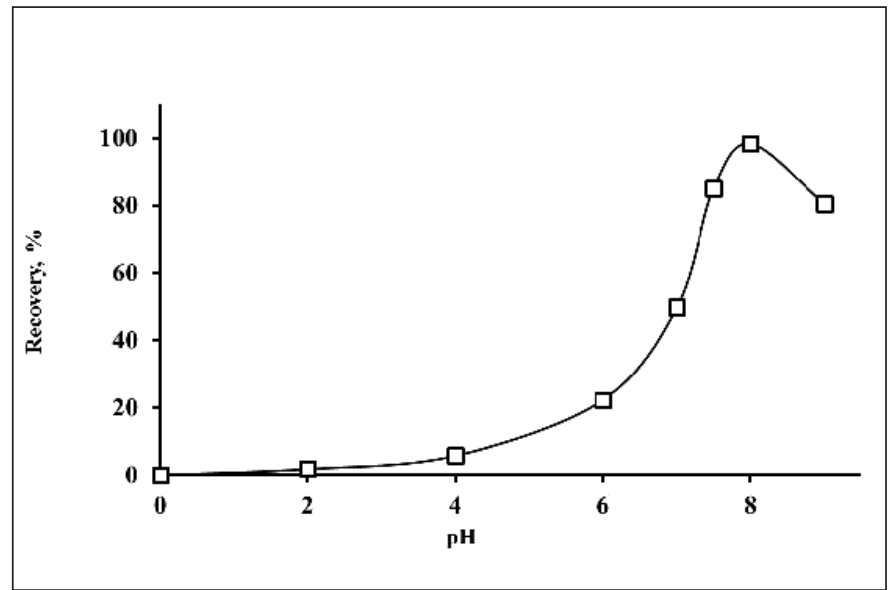

Fig 1. Evaluation of the effect of $p H$ value on the recovery of Cd(II) $(N=3)$.

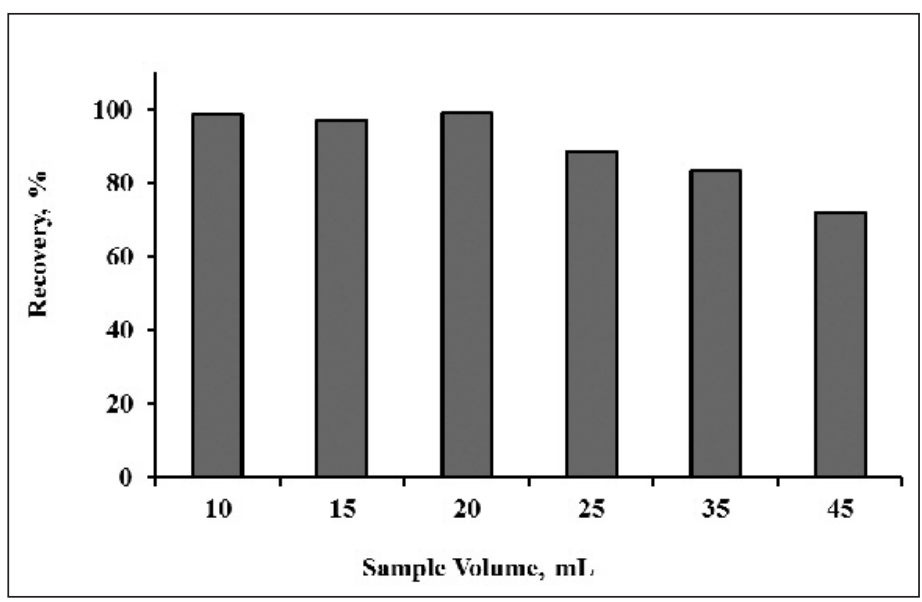

Fig. 3. Effect of sample volume on the (\%) recovery of $\mathrm{Cd}(\mathrm{II})(\mathrm{N}=3)$

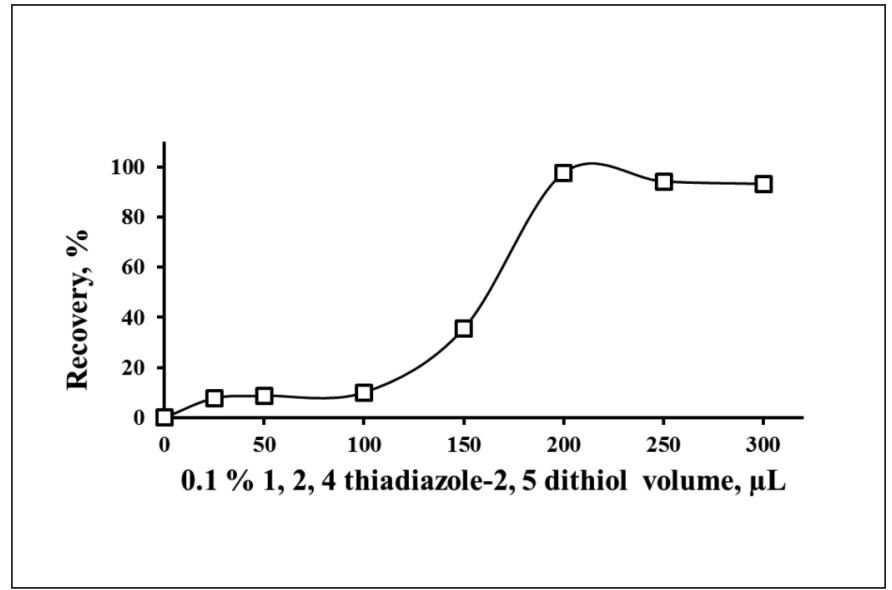

Fig. 2. Evaluation of the effect of the quantity of ligand on the (\%) recovery of $\mathrm{Cd}(\mathrm{II})(\mathrm{N}=3)$.

TABLE II

Optimum Condition for Cd(II) Supramolecular Microextraction

\begin{tabular}{lc}
\hline Parameters & $\begin{array}{c}\text { Optimum } \\
\text { Values }\end{array}$ \\
\hline pH value of sample solution & 8 \\
Amount of $0.1 \% 1,2,4$ & \\
thiadiazole-2, 5 dithiol & $200 \mu \mathrm{L}$ \\
Amount of tetrahydrofuran & $600 \mu \mathrm{L}$ \\
Amount of 1-decanol & $200 \mu \mathrm{L}$ \\
Sample volume & $20 \mathrm{~mL}$ \\
\hline
\end{tabular}


procedure for Cd(II) was investigated by addition/recovery tests of a tap water sample from Erciyes University, Kayseri, Turkey (Table V). The procedure is applicable in the presence of different concentrations of Cd(II) where the recoveries were not less than 99\%. For further optimization, certified reference materials TMDA 64.2 and TMDA 53.3 Water were applied (Table VI). The concentrations found by using the presented procedure were in agreement with the certified values.

Different samples such as wastewater, seawater, dam water, valley water, and black pepper were used for the determination of Cd(II) content. Table VII lists the obtained results which reveal that the developed procedure is applicable and independent of type of matrix.

\section{CONCLUSION}

A microextraction procedure, based on the application of tetrahydrofuran with 1-decanol to form a supramolecular solvent to separate Cd(II), was optimized. The 1,2,4thiadiazole-2,5-dithiol as ligand plays an important role for Cd(II) separation and recovery. The maximum operating conditions were a

TABLE III

Effect of Some Common Interfering Ions on the Recovery (\%) of $\mathrm{Cd}(\mathrm{II})(\mathrm{N}=3)$

\begin{tabular}{lrlc}
\hline Ions & $\begin{array}{c}\text { Concentration } \\
\left.(\mu \mathrm{g} \mathrm{mL})^{-1}\right)\end{array}$ & Added as: & $\begin{array}{c}\text { Recovery } \\
(\%)\end{array}$ \\
\hline $\mathrm{K}^{+}, \mathrm{Cl}^{-}$ & 2000 & $\mathrm{KCl}$ & $99.5 \pm 0.5$ \\
$\mathrm{Mg}^{2+}$ & 800 & $\mathrm{Mg}\left(\mathrm{NO}_{3}\right)_{2} \cdot 6 \mathrm{H}_{2} \mathrm{O}$ & $98.5 \pm 0.3$ \\
$\mathrm{Ca}^{2+}$ & 800 & $\mathrm{CaCl}_{2}$ & $99.5 \pm 0.4$ \\
$\mathrm{SO}_{4}^{2-}$ & 500 & $\mathrm{Na}_{2} \mathrm{SO}_{4}$ & $98.0 \pm 0.6$ \\
$\mathrm{~F}^{-}$ & 500 & $\mathrm{NaF}$ & $96.5 \pm 0.4$ \\
$\mathrm{Ni}^{2+}$ & 5 & $\mathrm{Ni}\left(\mathrm{NO}_{3}\right)_{2} \cdot 6 \mathrm{H}_{2} \mathrm{O}$ & $98.0 \pm 0.6$ \\
$\mathrm{Cu}^{2+}$ & 10 & $\mathrm{Cu}\left(\mathrm{NO}_{3}\right)_{2} \cdot 3 \mathrm{H}_{2} \mathrm{O}$ & $100.0 \pm 0.4$ \\
$\mathrm{Fe}^{3+}$ & 5 & $\mathrm{Fe}\left(\mathrm{NO}_{3}\right)_{3} \cdot 9 \mathrm{H}_{2} \mathrm{O}$ & $96.0 \pm 0.4$ \\
$\mathrm{Zn}^{2+}$ & 5 & $\mathrm{Zn}\left(\mathrm{NO}_{3}\right)_{2}$ & $97.0 \pm 0.8$ \\
$\mathrm{CO}_{3}{ }^{2-}$ & 2000 & $\mathrm{Na}_{2} \mathrm{CO}_{3}$ & $97.0 \pm 0.4$ \\
$\mathrm{NO}_{3}{ }^{-}$ & 2000 & $\mathrm{KNO}_{3}$ & $99.0 \pm 0.4$ \\
$\mathrm{Na}^{+}$ & 8000 & $\mathrm{NaCl}$ & $96.0 \pm 0.3$ \\
\hline
\end{tabular}

TABLE IV

Comparison Between Proposed Procedure and Other Methods Reported in the Literature for $\mathrm{Cu}$ Determination

\begin{tabular}{lll}
\hline Preconcentration Method & LOD $\left(\mu \mathrm{g} \mathrm{L}^{-1}\right)$ & Ref. \\
\hline Dispersive liquid-liquid microextraction (DLLME) & 1.0 & $(55)$ \\
Dispersive liquid-liquid microextraction (DLLME) & 0.4 & $(56)$ \\
On-line solvent extraction & 0.003 & $(57)$ \\
Cloud Point Extraction (CPE) & 0.006 & $(58)$ \\
Cloud Point Extraction (CPE) & 0.31 & $(59)$ \\
Microprecipitation & 0.25 & $(60)$ \\
Supramolecular microextration (SME) & 0.46 & This \\
& & study \\
\hline
\end{tabular}




\section{ACKNOWLEDGMENTS}

The authors extend their appreciation to the International Scientific Partnership Program ISPP at King Saud University for funding this research work through ISPP \#0029.

Received July 6, 2016.

\section{REFERENCES}

1. O. Turkoglu and, M. Soylak, and I. Belenli, Collect. Czech. Chem. C. 68, 1233 (2003).

2. M. Soylak, and O. Turkoglu, J. Trace Microprobe T., 17, 209 (1999).

3. T.Y. Gorgulu, O.D. Ozdemir, A.S. Kipcak, M.B. Piskin, and E.M. Deru, Appl. Biol. Chem. 59, 425 (2016).

4. U.A. Barbosa, I.F. dos Santos, A.M.P. dos Santos, and S.L.C. Ferreira, Anal. Lett. 49, 799 (2016)

5. M. Soylak and L. Elci, J. Trace Microprobe T., 18, 397 (2000).

6. M. Gebrelibanos, N. Megersa, and A.M. Taddesse, Int. J. Food. Contam. 3, 2 (2016). DOI 10.1186/s40550-016-0025-7

7. I. Narin, M. Soylak, and L. Elci, Anal. Lett. 34, 1935 (2001).

8. V.G. Bizarro, E.J. Meurer, and F.R.P. Tatsch, Ciencia Rural 38, 247 (2008).

9. A. Tumuklu, M. Çiflikli, and F.Z. Özgür, Asian J. Chem., 20, 6376 (2008).

10. M. Kramarova, P. Massanyi, A. Jancova, R. Toman, J. Slamecka, F. Tataruch, J. Kovacik, J. Gasparik, P. Nad, M. Skalicka, B. Korenekova, R. Jurcik, J. Cubon, and P. Hascik, Bull. Vet. Inst. Pulawy 49, 465 (2005).

11. U. Divrikli, M. Soylak, L. Elci, and M. Dogan, J. Trace Microprobe T. 21, 713 (2003).

12. M.N. AlKathiri and A.F. AlAttar, Bull. Environ. Contam. Toxicol. 58, 726 (1997).

13. A.A. AlWarthan and H.M. AlSwaidan, Arab. Gulf. J. Sci. Res.
J., 13, 453 (1995).

14. M. Tuzen and M. Soylak, J. Hazard. Mater. 164, 1428 (2009).

15. Y. Yang, F.S. Zhang, H.F. Li, and R.F. Jiang, J. Environ. Manage. 90, 1117 (2009).

16. D. Mendil, O.F. Unal, M. Tuzen, and M. Soylak, Food Chem. Toxicol. 48, 1383 (2010).

17. J.S. Barin, F.R. Bartz, V.L. Dressler, J.N.G. Paniz, and E.M.M. Flores, Anal. Chem. 80, 9369 (2008).

18. A. Shokrollahi, M. Ghaedi, O. Hossaini, N. Khanjari, M. Soylak, J. Hazard. Mater. 160, 435 (2008).

19. M.A. Zazouli, M. Shorkzadeh, S. Fathi, and H. Izanlo, Afr. J. Biotechnol. 7, 3689 (2008).

20. P. Nad, P. Massanyi, M. Skalicka, B. Korenekova, V. Cigankova, and V.Almasiova, J Environ. Sci. Heal. A 42, 2017 (2007).

21. M. Soylak, L. Elci, and M. Dogan, Anal. Lett. 26, 1997 (1993).

22. M. Karimi, A.M.H. Shabani and S. Dadfarnia, J. Braz. Chem. Soc. 27, 144 (2016).

23. M. Tuzen, M. Soylak, D. Citak, H.S. Ferreira, M.G.A. Korn, and M.A. Bezerra, J. Hazard. Mater. 162, 1041 (2009).

24. S. Kaur, T.P.S. Walia, and R.K. Mahajan, J. Environ. Eng. Sci. 7, 83 (2008).

25. A. Uzun, M. Soylak, L. Elci, and M. Dogan, Asian J. Chem., 14, 1277 (2002).

26. S. Dadfarnia, A.M. Haji Shabani, and M. Amirkavei, Turk. J. Chem., 37, 746 (2013).

27. U. Divrikli, A.A. Kartal, M. Soylak, and L. Elci, J. Hazard. Mater., 145, 459 (2007).

28. A. Denizli, E. Piskin, and B. Salih, Turk. J. Chem. 19, 296 (1995).

29. H. Cesur, Turk. J. Chem., 27, 307 (2003).

30. Y.E. Unsal, M. Tuzen, and M. Soylak, Turk. J. Chem., 38, 173 (2014).

31. Z.A. ALOthman, E. Yilmaz, M. Habila, and M. Soylak, Desalin. Water Treatmt. 51, 6770 (2013).

32. M. Amirkavei, S. Dadfarnia and A.M.

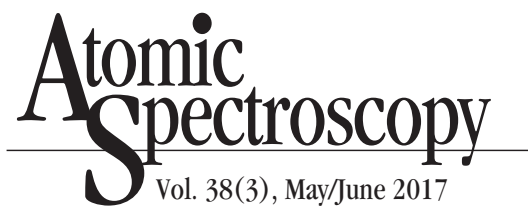

Haji Shabani, Quim. Nova 36, 63 (2013).

33. R. Yousefi and F. Shemirani, Anal. Chim. Acta 669, 25 (2010).

34. C. Caballo, M.D. Sicilia, and S. Rubio, Talanta 119, 46 (2014).

35. C. Caballo, M. D. Sicilia, and S. Rubio, Anal Bioanal. Chem. 407, 4721 (2015).

36. Q. Yang, W. Su, X. Jiang, and X. Chen, Int. J. Environ. Anal. Chem. 94, 812 (2014)

37. M. Peyrovi and M. Hadjmohammadi, J. Chromatogr. 980B, 41 (2015).

38. F. Aydin, E. Yilmaz, and M. Soylak, RSC Adv. 5, 40422 (2015).

39. E. Yilmaz and M. Soylak, Talanta 126, 191 (2014).

40. S. Saracoglu, M. Soylak, D.S.K Peker, L. Elci, W.N.L. dos Santos, V.A. Lemos, and S.L.C. Ferreira, Anal. Chim. Acta 575, 133 (2006).

41. M. Soylak, Y.E. Unsal, N. Kizil, and A. Aydin, Food Chem. Toxicol., 48, 517 (2010)

42. M. Ghaedi, M. Montazerozohori, F. Marahel, M.N. Biyareh, and M. Soylak, Chin. J. Chem. 29, 2141 (2011).

43. I.M.M. Kenawy, W.I. Mortada, Y.G. Abou El-Reash, and A.H. Hawwas, Can. J. Chem. 94, 221 (2016).

44. M. Soylak and E. Yilmaz, Desalination 275, 297 (2011)

45. L. Hu, Y. Cai, and G. Jiang, Chemosphere 156, 14 (2016)

46. M. Sheibani, F. Marahel, M. Ghaedi, M. Montazerozohori, and M. Soylak, Toxicol. Environ. Chem. 93, 860 (2011).

47. M. Soleimani and Z.H. Siahpoosh, J. Applied Chem. Research 9, 7 (2015).

48. M. Ghaedi, K. Niknam, E. Niknam, K. Mortazavi, K. Taheri, and M. Soylak, J. Chin. Chem. Soc. 57, 275 (2010).

49. M. Firlak, S. Cubuk, E.K. Yetimoğlu, and M.V. Kahraman, Chem. Pap. 70, 757 (2016).

50. H. Erdogan, O. Yalcinkaya, and A.R. Turker, Turk. J. Chem., 40, 772 (2016). 51. N. Khan, T.G. Kazi, M. Tuzen, and M. Soylak, Desalin. 
Water Treatmt. 55, 1088 (2015).

52. C. Polat, V. Eyupoglu, and O.N. Sara, AIP Conf. Proc. 1726, 020110 (2016); DOIi: 10.1063/1.4945936

53. R. Gurkan and M. Eser, J. Iran. Chem. Soc. 13, 1579 (2016).

54. X. Xu, M. Zhang, L. Wang, S. Zhang, M. Liu, N. Long, X. Qi, Z. Cui, L. Zhang, Food Anal. Methods 9, 1696 (2016).

55. A. Afkhami, T. Madrakian, H. Siampour, J. Hazard. Mater. 138, 269 (2006).

56. S.Z. Mohammadi, Y.M. Baghelani, F. Mansori, T. Shamspur, D. Afzali. Quim. Nova 35, 198 (2012).

57. A.N. Anthemidis, G.A. Zachariadis, and J.A. Stratis, J. Anal. At. Spectrom. 18, 1400 (2003).

58. X. Zhu, X. Zhu, and B. Wang, Microchim. Acta 154, 95 (2006).

59. J.L. Manzoori and G. K. Nezhad, Anal. Chim. Acta 521, 173 (2004).

60. Z.A. ALOthman, M.A. Habila, S.M. Alfadul, E. Yilmaz and M. Soylak. Anal. Methods 8, 3545 (2016).

61. M. Soylak, S. Saracoglu, L. Elci, and M. Dogan, Int. J. Environ. Anal. Chem. 82, 225 (2002). 